\title{
Hegemony in Effective Communication on the Modern Health Services During Pregnancy, Give Birth, and Postpartum in Baduy Communities
}

\author{
Ratih Ariningrum ${ }^{1}$, Vita Kartika ${ }^{2}$, Rozana Ika Agustiya ${ }^{2} \&$ Choirum Latifah $^{2}$ \\ ${ }^{1}$ Researcher of Management and Health Policy in Centre of Research and Development of Humaniora and \\ Management of Health, National Institute of Health Research and Development, Indonesia \\ ${ }^{2}$ Researcher of Health Humanities in Centre of Research and Development of Humaniora and Management of \\ Health, National Institute of Health Research and Development, Indonesia \\ Correspondence: Ratih Ariningrum, Centre of Research and Development of Humaniora and Management of \\ Health, National Institute of Health Research and Development. Jl. Percetakan Negara 29. Jakarta 10560. \\ Indonesia. Tel: 62-815-967-2180.
}

Received: July 27, 2020 Accepted: November 5, 2020 Online Published: November 20, 2020

doi:10.5539/gjhs.v13n1p28 URL: https://doi.org/10.5539/gjhs.v13n1p28

\begin{abstract}
Kanekes Village, where Baduy people live, is the biggest contributor to maternal deaths in the District of Lebak. Baduy awareness to check pregnancy at midwives has begun to increase, but for childbirth and childbirth examination has not been carried out. That is because there is a culture in the Baduy community regarding childbirth itself, as well as their adherence to the rules that have been issued by traditional leaders. The research uses a qualitative approach with the Participatory Action Research (PAR) approach. This study aims to examine the constraints and analyze the process of the formation of relationships between health workers, cadres, and heads of RT with the Baduy community in effective communication to improve modern health services during pregnancy, give birth, and postpartum in the Baduy community. The results showed that modern health services can be applied to the behavior of pregnancy, childbirth, and the puerperal of the Baduy community if the agents of change (organic intellectual) can change the idea of the modern health service into an ideology, then popular belief is obtained, then hegemony is formed from the agents of change. The final stage is that the country must be able to accommodate this effort. The efforts of agents of change (organic intellectuals) from the idea of modern health services to the created hegemony are sought by effective communication. Implementation of effective communication is pursued by provding explanations that are easily understood by the public through simulations.
\end{abstract}

Keywords: hegemony, modern health services, pregnancy, childbirth, postpartum

\section{Introduction}

The culture of childbirth that occurs in the Baduy community is the culture of childbirth performed by pregnant women themselves before labor or without birth attendants. Not infrequently in the process of labor, the mother experienced bleeding or complications of labor that ended in death because the mother was late getting medical help. This condition can occur, because pregnant women in Baduy are not accustomed to carrying out routine pregnancy examinations in health workers and delivery in health facilities. They still entrust the paraji shaman $t$ check their pregnancy. The paraji helps the mother and baby after the delivery proces.

Cases of maternal deaths in Lebak Regency in 2018 there were 47 deaths or 195/100,000 live births, while infant deaths reached 450 cases or 19.7/1000 live births. That number has increased from 2017, which is as many as 40 cases of maternal death or as much as 166/100,000 and as many as 431 infant deaths or as much as 18.1/1000. Lebak Regency ranks third in terms of high maternal mortality rates. Kanekes Village, where Baduy people live, is the biggest contributor to the number of deaths in Lebak Regency. Childbirth itself contributes to the cause of maternal death.

To support the program to accelerate the reduction of Maternal Mortality Rate (MMR) and Infant Mortality Rate (IMR) in the Baduy community, in 2019 an activity was carried out to help open mindsets and provide understanding related to the health of pregnancy and birth. The implementation of these activities is by building effective communication in an integrated manner with traditional rituals or ceremonies hat are usually carried out during the process of pregnancy and birth in the Baduy community. This approach will facilitate the transfer of 
knowledge related to understanding pregnancy and birth health through modern health services. It is hoped that the provision of effective communication interventions will also enhance the insights of the Baduy community so that they can think critically about modern health services. Hafaz, said that there is a relationship between competence (in this case increasing insight) with critical thinking so that someone who has good insight will be easier to apply his mindset. Therefore, by providing effective communication, it is expected that the three target groups can continue the transfer of knowledge to the Baduy community, especially pregnant and childbirth women. So, they will routine examine pregnancy from the beginning of pregnancy until delivery. Delivery by midwife is also expected to increase.

In previous years research indicated that there were three targets for establishing effective communication in the Baduy community. The three targets are midwives, cadres and RT heads. In 2019 the research team seeks to implement interventions towards these three targets and empower various components in the community to improve modern health services. There is a relationship stage that developed when the modern health service program was developed in the Baduy community. These stages can be used as learning if a policy is applied to people with specific cultures.

Gramsci's hegemony approach is used to analyze the implementation of effective communication in the implementation of modern health services during pregnancy, childbirth, and postpartum. Gramsci (1987) has written many things in Prison Notebooks. A collection of writings containing various things that can be used in social life. Faruk (1999) argues that there are at least six key concepts in Gramsci's thinking, namely culture, hegemony, ideology, popular belief, intellectuals, and the state. The hegemony of organic intellectuals is needed about to with concerning the ideology developed. The existence of an ideology about something at first might be immediately accepted without opposition. In reality, after the activity is running, there are some obstacles or disagreements about it. Such a situation requires the existence of hegemony from the disseminator of the ideology by considering the local culture so that other parties can be embraced to lead to a conducive situation that supports the smooth running of an idea. Ideology can be accepted by the community if it can be accepted by the common sense of the community, so it is considered not contrary to local culture. In the end, ideology is truly acceptable in people's lves and becomes something popular and trusted by them.

The process of creating hegemony requires what is called a 'historical bloc'. The historical bloc is an alliance of various social forces that are united politically in a set of hegemonic ideas. Hegemony itself is created through the practiceof submission and consent. The idea owner must be able to create a 'historical bloc' to fight for its ideas into a universal worldview. Therefore, 'ideas' play an important role. For a group to submit and win the approval of another group, it must 'import' ideas. Therefore, for Gramsci, an idea will only find its transformative momentum if it becomes an ideology. The ideology must have a material basis, be driven by an 'intellectual', and then become a universal view (Sugiono, 1999).

The concept of hegemony from Gramsci can be used for the application of new things which incidentally are not yet generally implemented in communities in certain areas. Initially, there were ideas in the form of modern health services during pregnancy, childbirth, and postpartum which would be applied to the Baduy community. The idea is difficult to apply because initial habits that exist in the Baduy community. For this reason, the idea must be encouraged by three target groups (midwives, cadres, and RT heads) who are termed as organic intellectual groups. The intellectual group must try to provide understanding so that modern health services can be understood, approved, and run by all levels of Baduy society. Therefore, modern health services must be the transformation from an idea into an ideology in the Baduy community. If this has happened, it can be said that the three target groups have gained "popular trust" from the community. If all community groups have accepted and implemented recommendations regarding modern health services in pregnancy, childbirth, and postpartum, then it can be said that the hegemony process has proceeded in that phase. For this reason, "the state" in this case is the center of public health and the Lebak District Health Office needs to accommodate the course of these activities.

The three target groups implementing effective communication are health workers (midwives), cadres, and RT heads. Effective communication is built by holding continuous meetings between the three targets with the Baduy community groups, conducting simulations to facilitate implementation in the field, and integrating traditional rituals or ceremonies that are usually carried out during the process of pregnancy and birth in the Baduy community.

\subsection{Research Objectives}

1. Assessing the obstacles of implementing modern health services during pregnancy, birth, and postpartum in the Baduy community. 2. Analyzing the relationship process between midwives, cadres, and heads of RT with the Baduy community in effective communication to improve modern health servces during pregnancy, birth, and 
postpartum in the Baduy community.

\section{Method}

In this study, the respondents of the study were all the people of Outer Baduy who resided in the Village of Kanekes, Subdistrict of Cisimeut, District of Lebak, Province of Banten. The selection of informants and agents of change in this study was done by purposive sampling. The informants in this study are policymakers and managers of the Maternal and Child of Health Program at the district, sub-district and village level, village officials, health workers, and health cadres who were willing to be interviewed. To further explore the culture and rituals in the Baduy community, in-depth interviews were conducted with several community leaders, traditional leaders, and kokolot who knew more deeply about the culture and rituals of the Baduy community during the process of pregnancy to childbirth. Interviews were also conducted with pregnant and post-partum mothers as well as toddler mothers in the Outer Baduy village to complete information about Baduy behavior. The informants are expected to be able to provide the necessary information as well as provide recommendations among those who are willing to become agents of change as agents of community in helping to socialize the implementation of modern health services for pregnant and giving birth mothers.

Change agents to be selected are community leaders, traditional leaders, and religious leaders, health cadres. They are Outer Baduy people who have a spirit of volunteerism, care, willingness, and sincerity to encourage the community to do modern health services during pregnancy, childbirth, and postpartum. The change agent selection based on the results of discussions with traditional leaders, the village head, the center of public health team, and the Lebak District Health Office team. Change agents need to be aware of the variousleadership styles and the situations where they would be most effective (Fletcher, 1988).

This research uses Participatory Action Research (PAR) method because it is done by building participation from all parties involved in the research including the research team, the Lebak District Health Office team, the center of public health team, the village team chaired by the village head, community leader consisting of traditional leaders and other informants around the research location to link the research process to the process of social change.

\section{Results}

\subsection{Assessing the Obstacles of Implementing Modern Health Services during Pregnancy, Birth, and Postpartum in the Baduy Community}

In the Baduy community, there is a culture of childbirth itself. Until now, still many people who give birth on their own, only assisted by immediate family members. Some people ask for a shaman's help if the baby is born. Batubara's research (Batubara, 2012) stated that of the 12 informants, ten people answered giving birth alone and two others with the shaman. They usually give birth in a narrow room, there should be no light and holding on to cloth tied to the wood on the ceiling of the house. At the time of the birth lighted incense and one of family member bursts of panglay (plants whose tubers such as ginger) from the family for the smooth delivery process. The term of traditional ecological knowledge has interchangeably used with various terms, including local knowledge, indigenous technical knowledge, and folk knowledge (Ellen \& Harris, n.d.). It can be defined as 'a cumulative body of knowledge, practice, and belief, evolving by adaptive processes and handed down through generations by cultural transmission, about the relationship of a living being (including humans) with one another and with their environment.

The independent birth process is usually carried out by mothers who give birth in Baduy. Previously, pregnant women also did not carry out antenatal care from the beginning of pregnancy to delivery, because they lived in a field. Many mothers give birth alone in the field without the help of midwives or shaman (paraji).

In the prenatal process, shaman usually helps to massage the stomach of a pregnant woman so that the fetus is in a good and correct position, or provide herbs for a smooth pregnancy during delivery. After childbirth, paraji helps the mother's healing during the postpartum, and if there are disturbances during breastfeeding, and helps care for the baby until the umbilical cord is removed. Paraji is also often regarded as shamans of all diseases, including diseases caused by spirits. They usually give information about plant information that can be used as a medicine, how to process, and use it. The treatment carried out by traditional healers is also accompanied by mantras or certain incantations. In the traditional hears of Baduy, there are paraji (shaman that help to give birth), panghulu (shamans who take care of deceased people), bengkong jalu (shaman for male circumcision), and bengkong bikang (shaman for female circumcision). Paraji not only takes care of the delivery but also helps from before to after delivery (Permana, 2009).

That habit creates its problems when the mother gives birth must be referred. Usually, for this purpose the process is complicated. Sometimes the family refuses to refer to the mother who is going to give birth. The reason the 
family is because the mother can still be cured with spells. Midwives must talk first with the heads of RT or local leaders so that it is not difficult to refer them. The results of Nurhayati and Sugiharto's research stated that most of the informants chose a traditional birth attendant as the main birth attendant, because of local traditions (Nurhayati $\&$ Sugiharto, 2019). In the Baduy tradition, the role of traditional leaders is very large in giving approval to refer mothers who will give birth. They rely more on the shaman to handle cases that need to be referred.

Obstacles in the community in choosing the way of delivery and utilizing health services are very influenced by the formal education of the Baduy mothers. The average Baduy has not received formal education because of the rules that are still held by residents not to change everything that already exists. Formal education is needed to open up mothers' insights in utilizing health services. Kusuma's research (Kusuma, 2018) explains that good education opens up mothers' insights to think broadly about the utilization of health services. The level of education and sources of information received by pregnant women influence knowledge about pregnancy and childbirth so that pregnant women can decide delivery in health care facilities.

The midwives who work in Kanekes Village are mostly residents of Leuwidamar istrict. They all live outside the Kanekes Village because according to the prevailing custom, they cannot build buildings in the Baduy community area. If childbirth is not carried out in a health facility, in this case, the center of public health, then there is an assumption that their services in helping with childbirth cannot be paid. That assumption is wrong because Permenkes no. 97 of 2014 Article 14 paragraph (1) which says that labor must be performed in a health service facility does not mean that there is a prohibition on midwives to deliver labor outside the health facility (Kemenkes, 2014).

Other obstacles to the health of pregnant women and post-partum mothers also relate to certain dietary at that time. Pregnant women in sub-village of seven have restrictions on eating certain fruits because they worry will happen something to their babies. Postpartum mothers usually only eat cassava/tubers only. They are usually not allowed to eat eggs and meat, because they worry that the mother's uterus is swollen. Midwife in sub-village of four explained that the postpartum mother in that sub-village is not allowed to eat fish, spicy food, and foods with coconut milk.

2. Analyzing the relationship process between midwives, cadres, and heads of RT with the Baduy community in effective communication to improve modern health services during pregnancy, birth, and postpartum.

Various obstacles when the implementation of modern health services during pregnancy, childbirth, and postpartum in the Baduy community arise an idea about improving modern health services. Modern health services in this case are efforts to examine the mother during pregnancy, childbirth, and examine the mother and baby during postpartum to health workers. Deliveries at health facilities are also expected to increase. The development of these ideas in the Baduy community is not easy, because of the culture of childbirth itself that has been on them. Therefore, midwives as the spearhead of pregnancy and childbirth health services can be regarded as organic intellectuals. In this case, the midwife is one of the agents of change. Other agents of change are cadres and heads of RT.

Organic intellectual functions to change the idea of modern health services into an ideology or something that can be accepted by the Baduy community. If the ideology has been accepted by society, then it can be said that organic intellectuals (midwives, cadres, and heads of RT) have gained popular trust. Efforts to gain trust from the community are carried out by providing understanding to the community. Understanding will arise if the community has enough knowledge from people who are trusted. For this reason, effective communication is carried out with the Baduy community. Effective communication is a continuous effort from midwives, cadres, and heads of RT to increase knowledge and insight of the Baduy community so that modern health services can be understood and applied during pregnancy, birth, and postpartum.

The initial step is to equip the three target groups, namely midwives, cadres, and heads of RT with various matters relating to modern health services during pregnancy, childbirth, and postpartum. Midwives are given material about health and cultural aspects that they must understand. While for cadres and heads of RT, the material provided is balanced between the problems of modern health services and certain cultures that are obstacles in their implementation. These three groups were also carried out simulations to clarify the steps that they had to apply to the community. The essence of the simulation is so that pregnant women get attention from cadres, heads of RT, and local public figures (kokolot). The aim is to make it easier for pregnant women to get modern health services.

The next step is to hold meetings at various groups and levels in the Baduy community. Community groups that have been described regarding modern health services during pregnancy, childbirth and postpartum are groups of pregnant women, husbands or family members of pregnant women, a shaman that help labor (paraji), and village 
officials. Baduy communities have traditional leaders who important role in decision making. Important decisions relating to the socio-cultural life of the community must be approved by traditional leaders. Meetings with various levels of Baduy traditional leaders were then held. The meeting began with the Kokolot, Kokolot Lembur, and Jaro Tujuh Tanggungan. The result of the meeting was the approval of modern health services for pregnant, childbirth, and postpartum. Community leaders also agreed to monitor and support examine mothers of pregnant and labor at midwives.

\section{Discussion}

The life of Baduy residents has a socio-cultural system that is based on local wisdom. Local wisdom can be interpreted as a way of life, knowledge, and life strategies that carried out by local communities in answering various problems, covering all elements of life; religion, science, and technology, social organization, language and communication, and art (Suparmini \& Setyawati, 2013). Local wisdom about pregnancy, childbirth, and postpartum is in the form of traditional ceremonies to achieve good conditions for mothers and babies. The traditional ceremonies are as one of the media to carry out effective communication. Midwives can interact more with residents in the target area if present at these traditional ceremonies. The presence of midwives on that traditional ceremonies can be used to convey messages relating to the health of the pregnancy, childbirth, and postpartum. At the ceremony usually a paraji present. The presence of paraji can be used by midwives to establish partnerships. It seems, for this time, still no high interest from the midwives to attend the traditional ceremonies. Midwives felt that they were not invited to the event. Midwife Ros, as a midwife who has long interacted with the Baduy community, shared some of her experiences while attending a traditional ceremony. He said that he was not invited to traditional ceremonies related to pregnancy, childbirth, and postpartum. Mrs. Ros attended at the various ceremonies by directly. She came to the homes of residents and helping mothers who were cooking for ceremonial purposes. The presence of Midwife Ros on that ceremony is one of the effective ways to approach citizens. Therefore, the research team also tried to make midwives more often present at the traditional ceremonies.

In the process of ongoing effective communication at various community groups and levels of traditional leaders, as well as integration with traditional ceremonies, this is where hegemony with the cultural approach of midwives, cadres, and heads of RT begins. The three groups are also called organic intellectuals. Organic intellectuals carry out a continuous approach so that the community and traditional leaders want to examine pregnancy, childbirth, and postpartum on health workers. These efforts were successful in the community. Pregnant women in the Baduy community began to examine their pregnancy by midwives and to be referred to health facilities. The momentum indicated that the three groups that carried out hegemony efforts had gained popular trust from the public. The situation also illustrates that the hegemony of organic intellectuals (midwives, cadres, and heads of RT) has been realized in changing the Baduy community's perception of modern health services for pregnant, childbirth, and postpartum.

During the meeting of pregnant women at the center of public health, the coordinating midwife and village midwives explained important themes that should be known by pregnant women. The first theme is about nutritious food for mothers, the second theme is about pregnancy examinations by midwives, the third theme is information about babies with Low Birth Weight (LBW) and ways to prevent it. This theme is also explored, because of the high prevalence of underweight and stunting toddlers. The prevalence of underweight in Baduy toddlers is $26.4 \%$. The prevalence of underweight for Baduy children is higher than the prevalence of underweight children in Indonesia as a result of the 2007 Basic Health Research (Badan Penelitian dan Pengembangan Kesehatan, 2007), which is $18.4 \%$. The overall stunted prevalence is $60.6 \%$. This prevalence is much higher than the prevalence of stunting of children under five years in Indonesia as a result of Riskesdas 2007 which is only around 36.8\% (Anwar \& Riyadi, 2009). The fourth theme is the signs of a problem pregnancy. The fifth theme concerning the integration of handling maternity mothers by midwife and paraji. Midwives provide help if bleeding occurs.

The coordinating midwife also explained the Mother and Child Health Book (KIA Book). The contents of the KIA Book were also elaborated so that the Baduy mothers better understand the pictures in that book. The first thing if there is a pregnant woman in the house, so the sticker posted on the door of the pregnant woman's house. Data on pregnant women who come to the posyandu are filled in the book. At the end of the meeting, Midwife Ros also appealed for pregnant women who began to feel heartburn to immediately notify the cadre, so that the cadre could immediately notify the midwife.

The support of community leaders from each village is different, some are ignorant, but also those who support. The community in sub-village of five explained that the traditional leaders were very supportive health workers. Health workers must permission from traditional leaders. A cadre in sub-village of seven tells us that community 
leaders support, but not many people come to the midwife. In essence, mothers are allowed by community leaders (kokolot) to be examined at posyandu or in health workers. Example: Customary leaders in Kampung Cempaka, Subvillage of two, and Kampung Ciwaringin, sub-village of three are very supportive as long as they do not violate custom. Community leaders and religious leaders in sub-village of two, five, six, seven, eight, and nine also support efforts in the health sector. Even so, in the whole of the sub-village, there are still many people who come to paraji (shaman) at 1-9 months of pregnancy, because the paraji have spells and massage mothers. So the awareness of citizens to check with health workers is still lacking.

The head of RT (neighborhood association) supported the health sector. The support from them to encourage residents to examine her pregnancy. The head oh RT heads also explained that midwives would not harm the community, but would improve the public health.

Pak Ijom, one of the heads of RT in sub-village of five said:

"Our life patterns have changed. This is one factor. So we must also follow the changes. "

The heads of RT also admitted that there were heads of RT who were less concerned about health issues. Therefore, at each meeting stressed the importance of three-party interaction to effective communication. The active interaction of the three components (midwives, cadres, and heads of RT) is needed. If there is one less active component it will disrupt the objectives to be achieved.

All efforts that have been carried out by organic intellectuals need to be contained by the state. The state in this case is the center of public health than the Lebak District Health Office. The efforts of the center of public health and the district health office are aimed at the change in community perception that can be continued.

The district health office is aware that the Baduy community in Kanekes has specific something for helping labor. Their large area makes it difficult to refer to mothers who need further medical treatment. A mother who was referred to was certainly accompanied by other family members. The family members who accompany her certainly place to stay. The employee of the district health office then discussed with the employee of the hospital, so that the place could be provided. After that, there is a rule that allowed a mother who was referred could be accompanied by three people for three days. They can stay in the room that has been provided by the hospital and they also get food. The effort was carried out because so far the existing waiting houses have not been utilized by the community. Maybe family members have looked for a place that is closer to the family member who is being treated. The employee of the district health office will give information about the hospital to refer to. Therefore, mothers who are referred must be reported to the district health office. Currently, the district health office has provided various innovations related to improving maternal and child health. Efforts have continued to be increased in the last four years. One effort is to develop the application of Healthy Ambu. Healthy Ambu application is an application to monitor pregnant women to be healthy. The application is an effort to support the regulation of Banten Governor number 26 of 2016, because the head of Lebak District is indeed very responsive to the health of mothers and children. Besides that, imah pangubaran (waiting for a house) was also established. Another effort is cadre training. All midwives re also encouraged to approach the community.

Efforts from the center of public health to improve maternal and child health are the delivery of information to the community, encouraging the community to be examined and giving birth to midwives, referring high-risk pregnant women, and reminding that all center of public health staff is committed to encouraging pregnant women to examine and give birth at the center of public health. The center of public health has also tried to the relationship with the head of village and community leaders to reduce the number of deaths. The supports are the form of their interaction with community empowerment efforts. Effective communication carried out by the team aims to increase community empowerment.

\section{Conclusion}

There is an idea to increase the implementation of modern health services during pregnancy, childbirth, and postpartum in the Baduy community. An idea can be accepted by the community if the idea is considered not contrary to local culture and some organic intellectual actors have changed into an ideology. Midwives, cadres, and heads of RT are agents of change or organic intellectuals who have succeeded in changing the idea of modern health services into something that can be accepted by the Baduy community. The actions of the agents of change that have succeeded in changing the views of the Baduy community towards modern health services indicate that they have gained the trust of the community (popular trust). The agents of change or organic intellectuals have been able to apply their hegemony to lead the public in implementing modern health services. The final stage is the state's efforts to oversee the modern health service policy for the Baduy community to be sustainable.

The efforts of agents of change (organic intellectuals) from the idea of modern health services to the created 
hegemony are developed by effective communication. Effective communication is an effort that is carried out continuously to communicate something that is the goal of the activity, in this case, is modern health services. In the Baduy community, there are several levels of traditional leaders. Effective communication is carried out in stages with these traditional leaders groups, so that, the modern health services get approval to be implemented in the Baduy community. The effort was carried out by considering the Baduy culture. Therefore, promotion about modern health services is also carried out through the presence of agents of change in traditional ceremonies relating to pregnancy, childbirth, and postpartum.

Implementation of effective communication is provided explanations that are easily understood by the public through simulations. The simulation of effective communication resulted in seven steps that must be considered by midwives, cadres, and head of RT in implementing modern health services. The seven steps are: 1. cadres go to pregnant women for data collection, 2. cadres come to the head of RT to report the results of the data collection, 3 . head of RT comes to pregnant women to deliver messages regarding examine pregnancy and childbirth at the midwife and complete population administration, 4. cadres submit baseline data to midwives, 5. midwives accompanied by cadres visit pregnant women to carry out examinations and deliver health messages, 6 . midwives with a head of RT visit to the kokolot. The kokolot is expected to support these activities, 7. midwives and cadres carry out promotive and preventive efforts include presence at traditional ceremonies related to pregnancy, childbirth, and postpartum.

\section{Recommendation}

1). Formulating policies for the implementation of effective communication based on various meetings that have been held with religious / community leaders and simulations that have been practiced between the community and cadres, religious/community leaders, and health workers.

2). Providing information about pregnancy and childbirth at traditional ceremonies.

3). Cisimeut Community Health Center and Lebak District Health Office monitor the implementation of a modern health service improvement system by means of effective communication.

4). Ensure the availability of a budget for cadres and budget for implementing maternal referral.

5). It is necessary to have additional health facilities in the form of auxiliary health centers or village health pos especially for bungur who are far from Cisimeut Community Health Center.

6). The need for improving the quality and retraining cadres of Kanekes Village.

7). There is a need for more intense support and coordination from the Health Office to the health workers at the Cisimeut Community Health Center.

8). The need to improve the overall quality of human resources in Cisimeut Community Health Center.

\section{Acknowledgements}

Special thanks to:

The community Baduy who gave information about culture of pregnancy, childbirth, and postpartum.

Head and all staffs in Cisimeut Center of Public Health who have provided meeting place and helped carry out research.

The coordinator midwife, all midwives, and cadres of posyandu in Kanekes Village who helped team researcher to approach to the Baduy community.

Heads of RT and head of village and all staffs in Kanekes Village who supported this research.

Head of Lebak District Health Office and all staffs who have gave information and supported this research.

Head of Center of Humaniora and Health Management Research and Development and Administration Team that financial support for this research.

Prof. Drg.Niniek L. Pratiwi, MKes who have guided to write this article.

\section{Competing Interests Statement}

The authors declare that there are no competing or potential conflicts of interest.

\section{References}

Afandi, A., Sucipto, M. H., \& Muhid, A. (2016). Modul participatory action research (PAR) untuk pengorganisasian masyarakat (community organizing). Lembaga Penelitian dan Pengabdian kepada 
Masyarakat, UIN Sunan Ampel Surabaya.

Anwar, F., \& Riyadi, H. (2009). Status gizi dan status kesehatan suku baduy. Jurnal Gizi dan Pangan, 4(2), 72-82. https://doi.org/10.25182/jgp.2009.4.2.72-82

Badan Penelitian dan Pengembangan Kesehatan. (2007). Riset Kesehatan Dasar Laporan Nasional 2007. Jakarta.

Batubara, S. (2012). Aspek Sosial Budaya yang Mempengaruhi Kematian Ibu Akibat Perdarahan Pada Masa Kehamilan dan Kelahiran Tahun 2012 (Studi Pengalaman Perempuan Baduy).

Ellen, R. F., Parkes, P., \& Bicker, A. (Eds.). (2000). Indigenous environmental knowledge and its transformations: critical anthropological perspectives (Vol. 5). Psychology Press. Retrieved October 5, 2020, from https://kent.rl.talis.com/items/A2805593-0556-6E3D-310B-294BC673432F.html

Faruk. (1999). Pengantar Sosiologi Sastra. Yogyakarta: Pustaka Pelajar.

Fletcher, E. P. (1988). The change agent as a catalyst in community education: Leadership styles and roles. Community Development Journal, 23(2), 107-109. https://doi.org/10.1093/cdj/23.2.107

Gramsci, A. (1987). Selections from the Prison Notebooks (Q. Hoare \& G. Nowell Smith, Eds.). New York: International Publishers.

Hafaz I. (n.d.). Memaksimalkan Proses Berpikir Kritis Oleh Perawat Dalam Melakukan Pelayanan Di Bidang Kesehatan. https://doi.org/10.31227/osf.io/gz82b

Kemenkes, R. I. (2014). Minister of Health Regulations No. 97 of 2014 Article 14 Paragraph.

Kusuma, R. (2018). The Relationship between Knowledge and Attitudes of Postpartum Mothers About Childbirth in health care facilities with the Selection of Childbirth Assistance. Scientific Journal, Batanghari University, Jambi. 18(3), 522. https://doi.org/10.33087/jiubj.v18i3.519

Nurhayati, N., \& Sugiharto, M. (2019). Perilaku Memilih Tenaga Penolong Persalinan pada Ibu Melahirkan di Desa Blambangan, Kecamatan Penengahan, Kabupaten Lampung Selatan, Indonesia. Buletin Penelitian Kesehatan, 47(3), 165-174. https://doi.org/10.22435/bpk.v47i3.1468

Susanti, S., Perdana, F., \& MP, R. S. (2017, October). Utilization of Medicinal Plants In The Community of Cipatat District, Bandung Barat Regency)(Study of Health Literacy) Utilization of Medicinal Plants In The Community of Cipatat District, Bandung Barat Regency)(Study of Health Literacy). In 4th Asia Pacific Education Conference (AECON 2017). Atlantis Press. https://doi.org/10.17510/wjhi.v11i1.145

Sugiono, M. (1999). Kritik Antonio Gramsci terhadap Pembangunan Dunia Ketiga. Yogyakarta: Pustaka Pelajar.

Suparmini, S., \& Setyawati, D. S. (2013). Pelestarian Lingkungan Masyarakat Baduy Berbasis Kearifan Lokal. Jurnal Penelitian Humaniora, 18(1), 11.

\section{Copyrights}

Copyright for this article is retained by the author(s), with first publication rights granted to the journal.

This is an open-access article distributed under the terms and conditions of the Creative Commons Attribution license (http://creativecommons.org/licenses/by/4.0/). 